\title{
Effect of Packaging Material, Storage Temperature and Duration on the Quality of Semi-Processed Adult House Cricket Meal
}

\author{
Edwin Kamau ${ }^{1}$, Christopher Mutungi ${ }^{2,3}$, John Kinyuru ${ }^{1}$, Samuel Imathiu ${ }^{1}$, C. Tanga ${ }^{3}$, H. Affognon ${ }^{5}$, S. Ekesi ${ }^{3}$, D. \\ Nakimbugwe $^{6}$ \& K. K. M. Fiaboe \\ ${ }^{1}$ Department of Food Science and Technology, Jomo Kenyatta University of Agriculture and Technology, P.O. \\ Box 62000-00200, Nairobi, Kenya \\ ${ }^{2}$ Department of Dairy, Food Science and Technology, Egerton University, P.O. Box 536-20115 Egerton, Kenya \\ ${ }^{3}$ International Centre of Insect Physiology and Ecology, P.O. Box 30772-00100, Nairobi, Kenya \\ ${ }^{4}$ International Institute of Tropical Agriculture (IITA), Plot NO. 25, Mikocheni Light Industrial Area, Dar es \\ Salaam, Tanzania \\ ${ }^{5}$ International Crops Research Institute for the Semi-Arid Tropics, BP 320, Bamako, Mali \\ ${ }^{6}$ Department of Food Technology and Nutrition, School of Technology, Nutrition and Bio-Engineering, Makerere \\ University, P.O. Box 7062, Kampala, Uganda \\ Correspondence: Edwin Kamau, Department of Food Science and Technology, Jomo Kenyatta University of \\ Agriculture and Technology, Po. Box 1017-00520 Nairobi, Kenya. E-mail: kamauedwin.ke@gmail.com
}

Received: October 31, 2017

Accepted: November 15, 2017 Online Published: November 29, 2017

doi:10.5539/jfr.v7n1p21

URL: https://doi.org/10.5539/jfr.v7n1p21

\begin{abstract}
Edible insects are widely consumed in different parts of the world and can serve as an alternative nutritional source to conventional foods. Nonetheless, little attention has been given to their quality and shelf life in different packages when exposed to different storage environments. In this study, the effect of storage temperature, duration and type of packaging on the storage stability of the adult house cricket meal was examined. The samples were boiled, solar dried, milled and packaged into polypropylene (PP), plastic (PL) and polyethylene (PL) packages. The samples were then stored for six months in refrigerated and ambient conditions where by changes in physical and biochemical attributes were monitored. Iodine values significantly decreased in all the packages while peroxide, $p$-anisidine and saponification values significantly increased. SFA, MUFA and PUFA contents reduced during storage although a higher tendency for MUFA and PUFA values was observed in the refrigerated samples. Total viable count (TVC) and yeast and molds counts significantly increased in storage. Three types of fungi; Aspergillus spp., Alternaria spp. and Penicillium spp. were isolated in all the packages. Overall color change steadily decreased with increase in storage time. Deterioration was higher in samples stored in ambient conditions than in refrigeration. The degree of deterioration in the two storage environments among the different packages was in the order; PP>PE $>$ PL. Although the PL package outperformed the other packages it is recommended to carry out sensory analysis and avoid post-processing contamination that can adversely affect the product quality and safety during storage.
\end{abstract}

Keywords: packaging, processing, safety, shelf life, stability, storage, quality

\section{Introduction}

The world population is growing at an alarming rate and it is estimated that by the year 2050 the planet earth will be home to about 9 billion people (Van Huis et al., 2013). The increasing world population is coupled with an increase in economic growth and urbanization among the population resulting in demand for adequate and high quality food (Van Huis et al., 2013). This implies that food production will have to be almost double the current production so as to be able to feed everyone (Van Huis et al., 2013). The resources that are currently being used in food production are already under stress and are impacting negatively on the environment (Klunder et al., 2012; Van Huis et al., 2013). In order to be able to satisfy the rising food demand currently and in the future, there is need to re-evaluate what we eat and how we produce it. Edible insects can be an alternative and reliable source of food. 
Edible insects are widely consumed in different parts of the world including Asia, Africa and America (Klunder et al., 2012; Obopile \& Seeletso, 2013; Van Huis et al., 2013). There are about 1800 species of insects that are used for human consumption globally (Jongema, 2011). Evidence from different researchers reveals that insects are rich in fat, protein and vitamins (Braide et al., 2011; Esther et al., 2015; Kinyuru \& Kenji, 2010; Obopile \& Seeletso, 2013; Van Huis et al., 2013). Their nutrient content is comparable to that of conventional livestock. The house cricket, Acheta domesticus (L.) (Orthoptera: Gryllidae) is a cosmopolitan omnivorous insect believed to be native in Southwestern Asia (Parajulee et al., 1993) but has now spread worldwide. It is commonly eaten in many parts of Asia particularly Thailand and is mostly preferred because of its soft body (Van Huis et al., 2013).

Although consumption of insects is widespread little attention has been given to their shelf life and safety. This is important especially where a large mass needs to be accumulated for commercialization purposes. Quality deterioration of edible insects commences during production and progresses through processing, distribution and storage (Mpuchane et al., 2000; Mujuru et al., 2014). The adult house cricket meal is comparable to other meat and edible insect products that are highly susceptible to microbial contamination and lipid oxidation which are the major factors that lead to loss of food quality and a reduction in shelf life (Kenawi, 2012). Food quality during storage also largely depends on the type of processing as well as the type of packaging used (Maionese et al., 2004). The use of low storage temperatures and packages with low gas permeability has been shown to increase the shelf life of many foods including vegetables (Giannuzzi et al., 2004). After wild harvesting or rearing, insects are killed by subjecting them to processes such as freeze drying, boiling, sun drying, frying or roasting (Kinyuru et al., 2009; Obopile \& Seeletso, 2013; Opara et al., 2012; Van Huis et al., 2013). In addition to killing the insects, these processes also help to preserve them by reducing microbial growth and prolong their shelf life. The processed insects can either be consumed as a whole or ground into flour and mixed with other ingredients. The processed products should be handled hygienically to prevent recontamination (Mujuru et al., 2014) and stored in water proof bags such as sealed plastic bags to avoid reabsorption of moisture(Van Huis et al., 2013).

Use of insects and their products is becoming more eminent and precautions need to be taken to reduce associated chemical and microbial hazards (Braide et al., 2011). Utilization of the adult house cricket meal as a source of protein for both humans and animals can go a long way especially now that conventional meat's prices are on the rise. Postharvest losses due to natural deterioration and unsuitable packaging methods that result in a product of poor quality and unpleasant taste act as a huge barrier in the use of these insects. The objective of this study was, therefore to assess the storage stability of semi-processed adult house cricket meal when stored at two different temperatures and in three different packages that are normally used. It is conceived that the results would inform the best storage temperature and package to store the product.

\section{Materials and methods}

\subsection{Experimental Material and Treatment}

Adult house cricket (Acheta domesticus) sample used in this study was obtained from International Centre for Insect Physiology and Ecology (ICIPE). The insects were blanched in boiling water for five minutes and dried in a solar drying tent to a constant weight. The sample was then pulverized using a kitchen blender (Phillips HR, 2850) to form the insect meal. An El-USB-1 data logger (Lascar electronics Inc. Pennsylvania, USA) was placed in the solar dying tent to record the temperature and relative humidity.

\subsection{Packaging, Storage and Sampling}

The adult house cricket (Acheta domesticus) processed sample, was subdivided into small portions of a $100 \mathrm{~g}$ each. The $100 \mathrm{~g}$ portions were then randomly filled into woven polypropylene (PP), high density polyethylene (PE) and plastic containers (PL) that were made of polypropylene. The PE and PP packages were sealed by twisting the open ends and tightly fastened. The PL packages came with their own screw lids. There was a total of 24 packages, 8 of each type of package. The packages were randomly divided into two equal halves (12 packages) with each half containing four of each of the packages. The two halves were then stored at refrigeration and ambient temperatures for a period of 180 days (6 months). An EL-USB-1 data logger (Lascar electronics Inc. Pennsylvania, USA) was placed in each of the storage environments to record the temperature, relative humidity and dew point levels during storage. Sampling was done during a trial set up to obtain baseline data and subsequently at 45 days intervals. To obtain samples for analysis at the different intervals, a single package of each of PP, PE and PL was picked (destructive sampling) from the two storage environments and the samples immediately analyzed for the different quality parameters. 


\subsection{Chemical Analysis}

Chemical changes in stored adult house cricket (Acheta domesticus) meal were assessed using peroxide value, saponification value, iodine value and p-anisidine values. The lipids were first extracted using Bligh and Dyer method (1959). The extracted lipids were used for the chemical analyses of the other parameters. Oxidation rate during storage was assessed by periodic determination of peroxide value (PV) and p-anisidine value (P-AV). AOAC official methods (AOAC, 1999) was used to determine the peroxide values. This method is based on the measurement of iodine produced from potassium iodide by peroxides present in a sample using iodometric titration. P-AV was determined according to IUPAC official method (IUPAC, 1987). This method is based on the reaction between aldehyde compounds and p-anisidine where the products of this reaction are spectrophotometrically determined. Iodine value (IV) and saponification value (SV) were determined gravimetrically according to the AOCS method (AOCS, 1992). All the chemical analyses were carried out in triplicate.

\subsection{Microbiological Analysis}

At every stage of the microbiological analysis, $5 \mathrm{~g}$ of the adult house cricket (Acheta domesticus) meal were weighed and diluted aseptically in $45 \mathrm{ml}$ of sterile peptone water. The mixture was then homogenized in a sterile polyethylene bag using a stomacher (400 circulator, seeward) for 1.5 minutes and serial dilutions were made thereafter in sterile peptone water. The microbial enumeration was performed on pour or surface plates after inoculating $0.1 \mathrm{ml}$ of the sample diluent using; plate count agar for Total aerobic mesophilic bacteria (TAMB) which was incubated at $30 \pm 1^{\circ} \mathrm{C}$ for 3days (Messer et al., 1985). Potato dextrose agar acidified with $10 \%$ tartaric acid for yeasts and molds incubated for 5 days at $25^{\circ} \mathrm{C}$ (Cambaztep et al., 2009). Violet red bile agar incubated at $37^{\circ} \mathrm{C}$ for 1 day for the enumeration of Enterobacteriaceae. Mac Conkey agar incubated at $37^{\circ} \mathrm{C}$ for 1 day for the enumeration of E.coli. Counts were expressed as $\log _{10}$ of colony forming units (CFU/g). Fungal cells were stained and identified using the lactophenol blue method for microscopic identification.

Salmonella was enumerated by first mixing a $5 \mathrm{~g}$ sample with $45 \mathrm{ml}$ nutrient broth and incubated at $37^{\circ} \mathrm{C}$ for 24 hours. The enriched sample was then inoculated in tetrathionate broth and incubated at $37^{\circ} \mathrm{C}$ for 24 hours. Enriched samples were then streaked on Salmonella Shigella agar. Salmonella isolates that grew as black colonies were then inoculated into TSI (Tripple Sugar Iron) slants to confirm which type of Salmonella species they were.

\subsection{Fatty Acid Analysis}

Oil samples for fatty acid analysis were obtained through the Bligh and Dyer method (1959). $2 \mathrm{~g}$ of a well ground and solar dried adult house cricket (Acheta domesticus) sample were extracted with $20.0 \mathrm{ml}$ of chloroform-methanol $(2: 1, \mathrm{v} / \mathrm{v})$ containing $10 \mathrm{mg} / \mathrm{L}$ of butylated hydroxyl toluene (BHT). Oil samples were derivatized according to a method reported by (Christie, 1989). Methyl esters $(1 \mu \mathrm{L}$ was injected into the gas chromatography (Shimadzu, GC-2010A series; Shimadzu, Tokyo, Japan) equipped with a flame ionization detector and a BPX70 capillary column of $30 \mathrm{~m} \times 0.32 \mathrm{~mm}$ i.d. (SGE, Melbourne, Australia). The initial temperature of $140^{\circ} \mathrm{C}$ was held for 2 minutes, which was then increased at $8{ }^{\circ} \mathrm{C} \mathrm{min}{ }^{-1}$ to $220{ }^{\circ} \mathrm{C}$ where it was held for another $5 \mathrm{~min}$. The oven, the injector and the detector pots were held at 140,240 and $260{ }^{\circ} \mathrm{C}$, respectively. The carrier gas was helium with a flow rate of $1.10 \mathrm{Ml} \mathrm{min}{ }^{-1}$ at 50:1 split ratio. The fatty acid peaks were identified by comparing the retention times with those of a mixture of standard fatty acid methyl esters (Sigma Chemicals, Deisenhofen, Germany)

\subsection{Color Measurement}

At each of the sampling stages after taking a sample for microbial analyses, the color of each of the samples was measured using a HunterLab Ultrascan spectrophotometer. The samples were first transferred into transparent plastic bags. The HunterLab L (lightness), a (redness) and b (blueness) values were then measured at six locations on each of the samples in the different packages and averaged. Derived color parameters; Hue angle $(\arctan \mathrm{b} / \mathrm{a})$, saturation $\left[\left(\mathrm{a}^{2}+\mathrm{b}^{2}\right)^{0.5}\right]$ and total color change $\left[\left(\mathrm{L}_{1}-\mathrm{L}_{2}\right)^{2}+\left(\mathrm{a}_{1}-\mathrm{a}_{2}\right)^{2}+\left(\mathrm{b}_{1}-\mathrm{b}_{2}\right)^{2}\right]^{0.5}$ were calculated. The spectrophotometer was calibrated on a white calibration plate.

\subsection{Statistical Analysis}

All analyses at each sampling stage were carried out in triplicate. Experimental data from each experiment were analyzed for variance using three way ANOVA taking into account the experimental factors; time, temperature and type of package. Microbiological data (Colony forming unit counts) were log transformed so as to be able to stabilize the variance among these counts. All the data was then subjected to analysis of variance using Stata SE version 12 (StataCorp LP, Texas, USA). Analysis of variance and covariance which combines features of both 
ANOVA and regression was further applied so as to determine effects of storage duration, temperature, type of packaging and the interaction effect of the three major factors. To be able to compare treatment outcomes at specific sampling stages three way ANOVA was performed and the means were separated using Bonferroni adjustment at $95 \%$ confidence level.

\section{Results and Discussion}

\subsection{Effect of Storage Time, Storage Environment and Type of Package on the Chemical Stability of the Adult House Cricket Meal}

Adult house crickets are rich in unsaturated fatty acids and therefore highly susceptible to oxidation during storage. In the present study, the lipid deterioration rate of adult house cricket was determined under different storage conditions and in different packages. Commonly employed chemical analyses including PV, P-AV, SV and IV were used to monitor the oil quality with increase in storage duration. Changes in PV, P-AV, SV and IV values of stored adult house cricket meal are as shown in tables 1 and 2. Results show that freshly boiled, solar dried and ground house cricket meal had a PV, SV, IV and P-AV value of 16.87 meq $\mathrm{O}_{2} / \mathrm{Kg}, 216.45 \mathrm{mg} \mathrm{KOH} / \mathrm{g}$, $129.00 \mathrm{mg} \mathrm{I} / \mathrm{g}$ and $12.34 \mathrm{P}-\mathrm{AV}$ units respectively. The IV of semi-processed adult house cricket compare well with those of fresh Oryctes rhinoceros larvae and Rhynchophorus phoenics that were ranging between 123.6-140.0 (Ekpo et al., 2009) suggesting that the cricket oil had a fairly high degree of unsaturation. The SV was higher than 184.20 recorded for dried and ground Imbrasia oyemensis larva (Akpossan \& Due, 2015) showing that the cricket oil had already undergone some degree of oxidation. This can be attributed to heating during semi-processing that accelerated the rate of oxidation (Kaleem et al., 2015). The PV was much higher than those found in fresh Macrotermes subhylanus and Ruspolia differens (green and brown) that were ranging between 0.13-0.19 (Kinyuru, 2010). This can also be attributed to heat processing that increased the oxidation rate, exposure of the samples during drying to oxygen and also microbial rancidity where micro-organisms use their enzymes to breakdown chemical structures in the oil (Kaleem et al., 2015).

Table 1. Changes in peroxide and p-anisidine values of semi-processed adult house cricket meal during storage in different packages and conditions

\begin{tabular}{|c|c|c|c|c|c|c|}
\hline \multirow{2}{*}{$\begin{array}{l}\text { Parameter } \\
\text { Days of storage }\end{array}$} & \multicolumn{3}{|l|}{ PV } & \multicolumn{3}{|l|}{ P-AV } \\
\hline & PL & $\mathrm{PE}$ & PP & PL & PE & PP \\
\hline \\
\hline 0 & $16.9 \pm 1.9^{\mathrm{m}}$ & $16.9 \pm 1.9^{\mathrm{m}}$ & $16.9 \pm 1.9^{\mathrm{m}}$ & $12.3 \pm 0.6^{\mathrm{b}}$ & $12.3 \pm 0.6^{\mathrm{b}}$ & $12.3 \pm 0.6^{\mathrm{b}}$ \\
\hline 45 & $26.5 \pm 1.1^{\text {bdj }}$ & $28.4 \pm 1.4^{\mathrm{bcd}}$ & $31.6 \pm 0.7^{\mathrm{abc}}$ & $13.2 \pm 0.2^{\mathrm{ab}}$ & $13.6 \pm 0.7^{\mathrm{abd}}$ & $13.9 \pm 0.4^{\mathrm{acd}}$ \\
\hline 90 & $34.2 \pm 1.8^{\mathrm{a}}$ & $36.7 \pm 1.5^{\mathrm{ae}}$ & $40.7 \pm 1.3^{\mathrm{ef}}$ & $15.5 \pm 0.3^{\text {cefi }}$ & $16.0 \pm 0.5^{\text {efgi }}$ & $17.0 \pm 0.5^{\mathrm{fgh}}$ \\
\hline 135 & $42.1 \pm 1.2^{\mathrm{efgh}}$ & $44.8 \pm 1.9^{\mathrm{fgh}}$ & $47.6 \pm 1.3^{\mathrm{hkl}}$ & $16.2 \pm 0.4^{\text {efghi }}$ & $16.9 \pm 0.6^{\text {efgh }}$ & $17.8 \pm 0.3^{\mathrm{hj}}$ \\
\hline 180 & $50.5 \pm 1.7^{\mathrm{kl}}$ & $52.2 \pm 1.5^{\ln }$ & $56.8 \pm 1.0^{\mathrm{n}}$ & $16.9 \pm 0.4^{\text {efgh }}$ & $17.6 \pm 0.4^{\mathrm{ghj}}$ & $18.7 \pm 0.2^{\mathrm{j}}$ \\
\hline \multicolumn{7}{|l|}{ Refrigeration } \\
\hline 0 & $16.9 \pm 1.9^{\mathrm{m}}$ & $16.9 \pm 1.9^{\mathrm{m}}$ & $16.9 \pm 1.9^{\mathrm{m}}$ & $12.3 \pm 0.6 b$ & $12.3 \pm 0.6^{\mathrm{b}}$ & $12.3 \pm 0.6 b$ \\
\hline 45 & $19.7 \pm 1.2^{\mathrm{im}}$ & $21.4 \pm 1.6^{\mathrm{ij}}$ & $33.3 \pm 1.1^{\mathrm{ac}}$ & $12.7 \pm 0.4^{\mathrm{ab}}$ & $12.4 \pm 0.3^{\mathrm{ab}}$ & $13.9 \pm 0.6 \mathrm{acd}$ \\
\hline 90 & $24.1 \pm 1.1^{\mathrm{dij}}$ & $28.4 \pm 1.3^{\mathrm{bcd}}$ & $\mathrm{Sp}$ & $12.9 \pm 0.3^{\mathrm{ab}}$ & $13.0 \pm 0.5^{\mathrm{ab}}$ & $\mathrm{Sp}$ \\
\hline 135 & $32.1 \pm 2.1^{\mathrm{abc}}$ & $34.1 \pm 1.9^{\mathrm{a}}$ & $\mathrm{Sp}$ & $13.9 \pm 0.2^{\mathrm{acd}}$ & $14.0 \pm 0.3^{\text {acd }}$ & $\mathrm{Sp}$ \\
\hline 180 & $41.1 \pm 1.9^{\mathrm{efg}}$ & $46.5 \pm 1.3^{\mathrm{ghk}}$ & $\mathrm{Sp}$ & $14.9 \pm 0.6^{\mathrm{cdi}}$ & $15.2 \pm 0.4^{\mathrm{cei}}$ & $\mathrm{Sp}$ \\
\hline
\end{tabular}

Data are means \pm standard deviations. Entries in the same column or row within each parameter followed by similar letters are not significantly different $(\mathrm{P}>0.05)$. Sp; Spoiled; PL-plastic; PE-Polyethylene; PP-Polypropylene

Variation in PV and P-AV of semi-processed adult house cricket meal during storage are as shown in table 1 . The $\mathrm{PV}$ and P-AV continually increased in all the samples during storage. PV is a measure of primary oxidation in oils and increases as the number of primary oxidation products produced increases (Kaleem et al., 2015). The $\mathrm{P}-\mathrm{AV}$ value is a measure of the secondary products of lipid oxidation including aldehydes and other carbonyl compounds in oxidized lipids (Shahidi, 1994). Increase in p-anisidine value during storage of a product can be attributed to the activity of lipase activity originating from the biological or microorganisms tissue (Boran et al., 2006) or to the conversion of primary oxidation products to secondary products (Maionese et al., 2004). Increase in PV during ambient storage was in the range of $102.5-141.1 \%$ at 90 days and $199.4-236.9 \%$ at 180 days while in refrigerated storage it was in the range of $42.6-68.4 \%$ at 90 days and $143.6-175.6 \%$ at 180 days. Increase in $\mathrm{P}-\mathrm{AV}$ during ambient storage was in the range of $7.1-12.6 \%$ at 90 days and $36.6-51.8 \%$ at 180 days while in refrigerated storage it was ranging from 4.6-5.5\% at 90 days and $20.8-23.4 \%$ at 180 days. These results indicate lipid oxidation and formation of both primary and secondary products of oxidation. The interaction effect of 
storage time, type of storage environment and type of package had a significant effect on both PV and P-AV. The individual factors; time, storage environment and type of package also had a significant effect on both parameters.

Table 2. Changes in saponification and iodine values of semi-processed adult house cricket meal during storage in different packages and conditions

\begin{tabular}{|c|c|c|c|c|c|c|}
\hline Parameter & SV & & & IV & & \\
\hline Days of storage & PL & PE & PP & PL & PE & PP \\
\hline \multicolumn{7}{|c|}{ Ambient } \\
\hline 0 & $216.5 \pm 1.8^{\mathrm{h}}$ & $216.5 \pm 1.8^{\mathrm{h}}$ & $216.5 \pm 1.8^{\mathrm{h}}$ & $129.0 \pm 1.6^{\mathrm{i}}$ & $129.0 \pm 1.6^{\mathrm{i}}$ & $129.0 \pm 1.6^{\mathrm{i}}$ \\
\hline 45 & $327.8 \pm 2.1^{\mathrm{b}}$ & $348.5 \pm 1.1^{\mathrm{c}}$ & $391.6 \pm 1.3^{\mathrm{e}}$ & $120.2 \pm 1.2^{\text {bdeg }}$ & $118.4 \pm 1.4^{\text {abde }}$ & $117.0 \pm 1.3^{\mathrm{abd}}$ \\
\hline 90 & $373.4 \pm 1.9^{\mathrm{d}}$ & $387.6 \pm 1.8^{\mathrm{e}}$ & $430.5 \pm 1.8^{\mathrm{f}}$ & $118.1 \pm 1.5^{\text {abde }}$ & $115.8 \pm 1.5^{\mathrm{abc}}$ & $115.1 \pm 1.5^{\mathrm{abc}}$ \\
\hline 135 & $412.5 \pm 1.7^{\mathrm{i}}$ & $432.6 \pm 1.6^{\mathrm{f}}$ & $460.6 \pm 1.6^{\mathrm{g}}$ & $115.2 \pm 1.4^{\mathrm{abc}}$ & $113.2 \pm 1.5^{\mathrm{acf}}$ & $111.2 \pm 1.5^{\mathrm{cf}}$ \\
\hline 180 & $457.5 \pm 1.7^{\mathrm{g}}$ & $470.5 \pm 1.1^{\mathrm{j}}$ & $492.1 \pm 1.5^{\mathrm{k}}$ & $113.9 \pm 1.6^{\mathrm{acf}}$ & $111.1 \pm 1.9^{\mathrm{cf}}$ & $109.0 \pm 1.1^{\mathrm{f}}$ \\
\hline \multicolumn{7}{|l|}{ Refrigeration } \\
\hline 0 & $216.5 \pm 1.8^{\mathrm{h}}$ & $216.5 \pm 1.8^{\mathrm{h}}$ & $216.5 \pm 1.8^{\mathrm{h}}$ & $129.0 \pm 1.6^{\mathrm{i}}$ & $129.0 \pm 1.6^{\mathrm{i}}$ & $129.0 \pm 1.6^{\mathrm{i}}$ \\
\hline 45 & $225.5 \pm 1.4^{\mathrm{a}}$ & $231.4 \pm 1.5^{\mathrm{a}}$ & $344.2 \pm 1.5^{\mathrm{c}}$ & $126.5 \pm 1.4^{\mathrm{hi}}$ & $126.0 \pm 1.4^{\mathrm{hi}}$ & $115.3 \pm 1.9^{\mathrm{abc}}$ \\
\hline 90 & $266.2 \pm 2.1^{1}$ & $282.6 \pm 1.9^{\mathrm{m}}$ & $\mathrm{Sp}$ & $124.2 \pm 1.3^{\mathrm{gh}}$ & $123.1 \pm 1.3^{\mathrm{egh}}$ & $\mathrm{Sp}$ \\
\hline 135 & $327.4 \pm 2.2^{\mathrm{b}}$ & $335.0 \pm 1.4^{\mathrm{n}}$ & Sp & $121.3 \pm 1.0^{\mathrm{degh}}$ & $119.2 \pm 1.1^{\text {bdeg }}$ & $\mathrm{Sp}$ \\
\hline 180 & $377.5 \pm 1.4^{\mathrm{d}}$ & $398.6 \pm 1.9^{\circ}$ & $\mathrm{Sp}$ & $117.1 \pm 1.2^{\mathrm{abd}}$ & $115.6 \pm 1.3^{\mathrm{abc}}$ & $\mathrm{Sp}$ \\
\hline
\end{tabular}

Data are means \pm standard deviations. Entries in the same column or row within each parameter followed by similar letters are not significantly different $(\mathrm{P}>0.05)$. Sp; Spoiled; PL-plastic; PE-Polyethylene; PP-Polypropylene

Change in SV and IV of semi-processed adult house cricket meal is as shown in table 2 . The SV significantly $(\mathrm{P}<0.05)$ increased during the storage period while the IV decreased. Hydrolysis and oxidation bring about lipid breakdown, forming free fatty acids or aldehydes and ketones as the end products. Increase in SV is not normally expected during this time but it is possible that the end products of oxidation such as aldehydes and ketones may contribute to increase in SV (Boran et al., 2006). The iodine value is related to the degree of unsaturation of the oil and a decrease in the iodine value shows a decrease in the level of unsaturation of the oil (Boran et al., 2006). Increase in SV in ambient storage was in the range of 72.5-98.9\% at 90 days and $111.4-127.4 \%$ at 180 days of storage while in refrigerated storage it was ranging from $23.0-79.4 \%$ at 90 days and $74.4-84.1 \%$ at 180 days of storage. The decrease in IV in ambient storage was in the range of $8.4-10.8 \%$ at 90 days and $11.7-15.5 \%$ at 180 days while in refrigerated storage it was ranging from $3.7-4.6 \%$ at 90 days and $9.2-10.4 \%$ at 180 days. The storage time, type of packaging and storage environment all had a significant $(\mathrm{P}<0.001)$ effect on both SV and IV The interaction effect between storage time, type of packaging and storage environment was also highly significant $(\mathrm{P}<0.001)$ on both parameters.

The decrease in IV and increase in SV, PV and P-AV were higher at ambient temperatures than in refrigerated conditions. Lipid oxidation rates are directly related to temperature (Flick et al., 1992) and thus oxidation at ambient conditions was expected to be higher than at refrigeration. The results of this study were similar to (Boran et al., 2006) who noted that increase in PV, P-AV and SV and decrease in IV were higher at $4^{\circ} \mathrm{C}$ as compared to $-18^{\circ} \mathrm{C}$. During storage most drastic change in IV, SV, PV and P-AV in ambient storage were seen at 0-45 days and at 135-180 days in refrigerated storage in all the packages. Drastic changes in ambient storage at the start of the experiment indicate that oxidation rate was highest during this period. This can be attributed to heat treatment and solar drying at the start of the experiment that could have promoted free radical formation in the insects lipids thus facilitating the high oxidation rate (Toci et al., 2013). Drastic changes in refrigerated environment seemed to have been delayed to between 135-180 days in all the packages. Thus can be attributed to the reduced temperature that resulted in a reduced oxidation rate.

Lipid oxidation in the different packages was occurring in the order PP>PE $>P L$. This can be attributed to differences in the rates of diffusion of both gases and water vapor across the packages. The woven PP package had a higher permeability to both gases and water vapor that could have favored a higher rate of oxidation. Different authors have also noted that polyethylene packages have a higher permeability to gases and water vapor than plastic polypropylene packages as shown in table 5.The results of this study are similar to (Adebola \& Halima, 2014) who also found microbial deterioration in stored Garri (food prepared from cassava roots) to decrease in the order of fertilizer bags $(\mathrm{PP})>$ polyethylene bags $(\mathrm{PE})>$ plastic buckets $(\mathrm{PE})$. 


\subsection{Effect of Storage Time, Storage Environment and Type of Package on the Fatty Acid Profile of the Adult House Cricket Meal}

Degradation in fatty acid profiles of boiled solar dried adult house cricket meal is as shown in table 3. Freshly boiled, solar dried and ground samples were composed of $27.1 \%$ saturated fatty acids (SFA), $21.0 \%$ monounsaturated fatty acids (MUFA) and 49.6\% polyunsaturated fatty acids (PUFA). The most dominant SFA were; palmitic acid (20.6\%) and stearic acid (4.7\%), the major MUFA was oleic acid (21.0\%) while the major PUFA was linoleic acid (40.44\%). The samples also contained appreciable amounts of n3 PUFAS i.e. DHA (1.8\%) and EPA (2.7\%). These results were comparable to Finke (2002) who also found that the major fatty acids in house crickets were palmitic, stearic, oleic and linoleic acids.

Table 3. Change in SFA, MUFA and PUFA content of semi-processed adult house cricket meal during storage in different packages and conditions

\begin{tabular}{|c|c|c|c|c|c|c|c|}
\hline \multirow[b]{2}{*}{ Parameter } & \multirow[b]{2}{*}{ Days } & \multicolumn{3}{|c|}{ Ambient storage } & \multicolumn{3}{|c|}{ Refrigerated storage } \\
\hline & & PL & $\mathrm{PE}$ & PP & PL & PE & PP \\
\hline \multirow[t]{5}{*}{ SFA } & 0 & $27.1 \pm 2.6^{\text {cde }}$ & $27.1 \pm 2.6^{\text {cde }}$ & $27.1 \pm 2.6^{\text {cde }}$ & $27.1 \pm 2.6^{\text {cde }}$ & $27.1 \pm 2.6^{\mathrm{cde}}$ & $27.1 \pm 2.6^{\mathrm{cde}}$ \\
\hline & 45 & $35.2 \pm 1.9^{\text {fhij }}$ & $41.2 \pm 1.9^{\mathrm{jk}}$ & $46.4 \pm 2.9^{\mathrm{k}}$ & $27.9 \pm 1.9^{\text {cdef }}$ & $31.2 \pm 2.3^{\mathrm{efh}}$ & $39.3 \pm 3.9^{\mathrm{ijk}}$ \\
\hline & 90 & $28.5 \pm 1.5^{\text {cdef }}$ & $32.1 \pm 1.9^{\text {efhi }}$ & $37.3 \pm 2.2^{\mathrm{hij}}$ & $18.9 \pm 2.1^{\mathrm{abg}}$ & $23.0 \pm 1.6^{\mathrm{acd} g}$ & $\mathrm{Sp}$ \\
\hline & 135 & $23.3 \pm 1.7^{\text {acdg }}$ & $25.2 \pm 1.5^{\operatorname{cdeg}}$ & $29.8 \pm 1.6^{\mathrm{def}}$ & $16.7 \pm 1.3^{\mathrm{ab}}$ & $16.9 \pm 1.2^{\mathrm{ab}}$ & $\mathrm{Sp}$ \\
\hline & 180 & $16.1 \pm 1.8^{\mathrm{ab}}$ & $17.0 \pm 1.4^{\mathrm{ab}}$ & $21.8 \pm 1.6^{\mathrm{acg}}$ & $13.1 \pm 1.7^{\mathrm{b}}$ & $13.7 \pm 1.0^{\mathrm{b}}$ & $\mathrm{Sp}$ \\
\hline \multirow[t]{5}{*}{ MUFA } & 0 & $21.0 \pm 0.6^{\mathrm{dg}}$ & $21.0 \pm 0.6^{\mathrm{dg}}$ & $21.0 \pm 0.6^{\mathrm{dg}}$ & $21.0 \pm 0.6^{\mathrm{dg}}$ & $21.0 \pm 0.6^{\mathrm{dg}}$ & $21.0 \pm 0.6^{\mathrm{dg}}$ \\
\hline & 45 & $22.6 \pm 1.1^{\mathrm{gi}}$ & $20.3 \pm 1.1^{\text {cdg }}$ & $17.0 \pm 1.2^{\mathrm{ceh}}$ & $25.4 \pm 1.2^{\mathrm{i}}$ & $24.8 \pm 1.2^{\mathrm{i}}$ & $15.8 \pm 1.3^{\text {bef }}$ \\
\hline & 90 & $19.2 \pm 1.0^{\mathrm{cdfg}}$ & $15.8 \pm 0.8^{\text {bef }}$ & $13.9 \pm 1.5^{\text {abe }}$ & $25.0 \pm 1.1^{\mathrm{i}}$ & $20.4 \pm 1.2^{\mathrm{cdg}}$ & $\mathrm{Sp}$ \\
\hline & 135 & $14.2 \pm 1.2^{\mathrm{abe}}$ & $12.6 \pm 1.0^{\mathrm{abh}}$ & $10.6 \pm 1.2^{\mathrm{ah}}$ & $20.3 \pm 0.8^{\mathrm{cdg}}$ & $18.3 \pm 0.7^{\mathrm{cdf}}$ & $\mathrm{Sp}$ \\
\hline & 180 & $12.2 \pm 1.5^{\mathrm{abh}}$ & $11.0 \pm 1.0^{\mathrm{ah}}$ & $9.9 \pm 0.5^{\mathrm{h}}$ & $18.7 \pm 1.4^{\mathrm{cdf}}$ & $14.2 \pm 1.2^{\mathrm{abe}}$ & $\mathrm{Sp}$ \\
\hline \multirow[t]{5}{*}{ PUFA } & 0 & $49.6 \pm 1.8^{1}$ & $49.6 \pm 1.8^{1}$ & $49.6 \pm 1.8^{1}$ & $49.6 \pm 1.8^{1}$ & $49.6 \pm 1.8^{1}$ & $49.6 \pm 1.8^{1}$ \\
\hline & 45 & $37.5 \pm 1.7^{\text {fhi }}$ & $35.8 \pm 1.7^{\text {efgh }}$ & $30.8 \pm 1.7^{\text {beg }}$ & $46.0 \pm 2.0^{\mathrm{kl}}$ & $43.6 \pm 1.9^{\mathrm{ik}}$ & $29.9 \pm 2.1^{\text {abe }}$ \\
\hline & 90 & $29.9 \pm 1.9^{\mathrm{abe}}$ & $28.1 \pm 2.5^{\mathrm{abd}}$ & $23.8 \pm 1.6^{\mathrm{acd}}$ & $41.5 \pm 1.5^{\mathrm{fik}}$ & $38.8 \pm 1.7^{\mathrm{fi}}$ & $\mathrm{Sp}$ \\
\hline & 135 & $26.1 \pm 1.8^{\mathrm{abcd}}$ & $23.3 \pm 1.6^{\mathrm{acd}}$ & $20.8 \pm 1.3^{\mathrm{cj}}$ & $37.3 \pm 1.8^{\text {fghi }}$ & $35.8 \pm 1.9^{\text {efgh }}$ & $\mathrm{Sp}$ \\
\hline & 180 & $22.5 \pm 1.8^{\mathrm{cdj}}$ & $20.1 \pm 1.9^{\mathrm{cj}}$ & $16.3 \pm 1.9^{j}$ & $31.7 \pm 1.6^{\text {begh }}$ & $28.7 \pm 2.0^{\mathrm{abd}}$ & $\mathrm{Sp}$ \\
\hline
\end{tabular}

Data are means \pm standard deviations. Means in the same column or row within a single parameter sharing common letters are not significantly $(\mathrm{P}>0.05)$ different. Sp; Spoiled; SFA-Saturated fatty acids; MUFA-Mono unsaturated fatty acids; PUFA-Poly unsaturated fatty acids

The SFA content seems to have increased in all the packages during the first 45 days of storage. Increase in saturated fatty acids during storage has been deemed to be the effects of decrease in other fatty (MUFA and PUFA) acids (Isdell et al., 2003). In the subsequent storage period the SFA content steadily decreased in all the packages. The MUFA and PUFA contents in turn steadily decreased during storage. Losses in both PUFA and MUFA contents during storage were in the range of $16.2-52.1 \%$ at 90 days and $10.73-67.0 \%$ at 180 days. The interaction effect between storage time, environment and type of packaging was highly significant $(\mathrm{P}<0.001)$ on the change in SFA, MUFA and PUFA contents during storage.

During storage highest decrease in the unsaturated fatty (MUFA and PUFA) acids were seen at 0-45 days in ambient storage and at 90-180 days in refrigerated storage in all the packages. In ambient storage conditions, a drastic decrease in unsaturated fatty acids at the beginning of the experiment indicated that oxidation was highest at this period. Heat treatment (boiling) during processing could have promoted free radical formation (Toci et al., 2013) thus promoting high oxidation rate at the beginning of the experiment. Drastic changes in refrigerated storage seemed to have been delayed to the period of between 90-180 days of storage. This can be attributed to the reduced temperature that resulted in a reduced oxidation rate. Fatty acid oxidation in the different packages was occurring in the order PP>PE $>\mathrm{PL}$. This can be attributed to differences in the rates of diffusion of both gases and water vapor across the packages. The woven PP package had a higher permeability to both gases and water vapor that could have favored a higher rate of oxidation. Different authors have also noted that polyethylene packages have a higher permeability to gases and water vapor than plastic polypropylene packages.

3.3 Effect of Storage Time, Storage Environment and Type of Package on the Microbial Stability of the Adult House Cricket Meal

Adult house cricket is nutritionally rich and can provide a suitable environment for the growth and proliferation 
of micro-organisms (Barroso et al., 2014; Rumpold \& Schluter, 2013; Van Huis et al., 2013). Five microbial parameters including TVC, Enterobacteriaceae, E-coli, yeasts and molds and salmonella were analyzed during storage of semi-processed adult house cricket meal at refrigeration and ambient conditions. The results of these are shown in table 4. Enterobacteriaceae, E-coli and Salmonella were not detected at the start of the experiment and during the entire storage period in all the samples. The results of this study were similar to Klunder et al. (2012) who also did not detect Enterobacteriaceae in boiled and dried house crickets and mealworm larvae. The absence of Enterobacteriaceae can be attributed to the boiling step where they were all killed. There also seems to have been minimized contamination during processing, packaging and storage as E-coli were not detected. Absence of salmonella was in line with other studies involving insects and insect products (Braide et al., 2011; Klunder et al., 2012; Mpuchane et al., 2000; Mujuru et al., 2014; Opara et al., 2012; Van Huis et al., 2013) where no salmonella was detected.

The total viable count for house cricket meal at the beginning of the experiment was found to be $5.18 \log \mathrm{CFU} / \mathrm{g}$. Although this was considerably high it was still the range of acceptability as compared to products such as cured meats and food stuffs that require further cooking where bacterial counts of up to $6.0 \mathrm{log} \mathrm{CFU} / \mathrm{g}$ are acceptable (Stannard, 1997). Presence of bacteria even after processing can be attributed to contamination during processing, packaging and storage (Braide et al., 2011; Mujuru et al., 2014; Opara et al., 2012). Yeasts and molds were not detected at the beginning of the experiment although later on they were present. Fungi and their spores are widely distributed in the air and may have contaminated the samples through the deposit of their spores when they were exposed to air during processing and packaging (Braide et al., 2011). This may also have been as a result of contamination through human contact and other post handling practices (Mujuru et al., 2014; Opara et al., 2012)

Table 4. Changes in TVC, yeasts and molds in semi-processed adult house cricket meal during storage in different packages and conditions

\begin{tabular}{|c|c|c|c|c|c|c|c|}
\hline & \multicolumn{7}{|c|}{ Microbial populations $(\log \mathrm{CFU} / \mathrm{G})$} \\
\hline \multirow[b]{2}{*}{ Parameter } & \multirow[b]{2}{*}{ Days } & \multicolumn{3}{|c|}{ Refrigerated storage } & \multicolumn{3}{|c|}{ Ambient storage } \\
\hline & & PL & PE & PP & PL & $\mathrm{PE}$ & PP \\
\hline \multirow[t]{5}{*}{ TVC } & 0 & $5.2 \pm 0.2^{\mathrm{j}}$ & $5.2 \pm 0.2^{\mathrm{j}}$ & $5.2 \pm 0.2^{\mathrm{j}}$ & $5.2 \pm 0.2^{\mathrm{j}}$ & $5.2 \pm 0.2^{\mathrm{j}}$ & $5.2 \pm 0.2^{\mathrm{j}}$ \\
\hline & 45 & $5.4 \pm 0.1^{\mathrm{gj}}$ & $5.4 \pm 0.1^{\mathrm{dgj}}$ & $5.9 \pm 0.2^{\mathrm{abdefg}}$ & $5.9 \pm 0.2^{\text {adefg }}$ & $6.0 \pm 0.1^{\text {abdef }}$ & $6.2 \pm 0.2^{\text {abcef }}$ \\
\hline & 90 & $5.5 \pm 0.2^{\operatorname{defg}}$ & $5.7 \pm 0.1^{\mathrm{dgj}}$ & $\mathrm{Sp}$ & $6.2 \pm 0.2^{\mathrm{abcf}}$ & $6.4 \pm 0.2^{\mathrm{abch}}$ & $6.6 \pm 0.1^{\mathrm{chi}}$ \\
\hline & 135 & $5.7 \pm 0.1^{\operatorname{deg}}$ & $6.2 \pm 0.1^{\text {abcef }}$ & $\mathrm{Sp}$ & $6.4 \pm 0.1^{\mathrm{bch}}$ & $6.6 \pm 0.1^{\mathrm{chi}}$ & $6.9 \pm 0.2^{\text {hi }}$ \\
\hline & 180 & $5.9 \pm 0.1^{\text {abdef }}$ & $6.3 \pm 0.1^{\mathrm{abc}}$ & $\mathrm{Sp}$ & $6.7 \pm 0.1^{\text {chi }}$ & $6.9 \pm 0.2^{\mathrm{hi}}$ & $7.1 \pm 0.2^{\mathrm{i}}$ \\
\hline \multirow{5}{*}{$\begin{array}{l}\text { Yeasts and } \\
\text { moulds }\end{array}$} & 0 & $\mathrm{Nd}$ & $\mathrm{Nd}$ & $\mathrm{Nd}$ & $\mathrm{Nd}$ & $\mathrm{Nd}$ & $\mathrm{Nd}$ \\
\hline & 45 & $1.6 \pm 0.1^{\mathrm{b}}$ & $1.6 \pm 0.1^{\mathrm{b}}$ & $2.5 \pm 0.2^{\mathrm{ef}}$ & $2.7 \pm 0.3^{\mathrm{ce}}$ & $3.0 \pm 0.6^{\mathrm{cde}}$ & $3.8 \pm 0.2^{\mathrm{a}}$ \\
\hline & 90 & $1.6 \pm 0.1^{\mathrm{b}}$ & $1.6 \pm 0.1^{\mathrm{b}}$ & $\mathrm{Sp}$ & $3.0 \pm 0.2^{\text {acde }}$ & $3.4 \pm 0.3^{\mathrm{acd}}$ & $3.8 \pm 0.4^{\mathrm{a}}$ \\
\hline & 135 & $1.6 \pm 0.2^{\mathrm{b}}$ & $1.7 \pm 0.2^{\mathrm{b}}$ & $\mathrm{Sp}$ & $3.1 \pm 0.2^{\text {acde }}$ & $3.4 \pm 0.2^{\mathrm{acd}}$ & $3.8 \pm 0.4^{\mathrm{ad}}$ \\
\hline & 180 & $1.9 \pm 0.2^{\mathrm{bf}}$ & $1.7 \pm 0.2^{\mathrm{b}}$ & Sp & $3.3 \pm 0.2^{\text {acde }}$ & $3.5 \pm 0.1^{\mathrm{acd}}$ & $3.8 \pm 0.2^{\mathrm{a}}$ \\
\hline
\end{tabular}

Data are means \pm standard deviations. Entries in the same column and row within each microbial parameter that are followed by the same letters are not significantly (P>0.05) different. Sp; Spoiled, Nd; Not detected; PL-plastic; PE-Polyethylene; PP-Polypropylene

Both TVC and yeast and mold count continually increased during the storage period. The adult house cricket meal provides a nutrient rich environment where different types of microorganisms can be able to grown and multiply. The increases were higher in ambient storage than in refrigeration. Growth rates of most microorganisms increase with increase in temperature. Furthermore, at low temperatures reaction rates of different enzymes in the microorganisms become much slower and the fluidity of the cytoplasmic membrane is reduced interfering with transport mechanisms (Mossel at al., 1995) thus reducing the growth rate. Mold that grew in our sample was later on identified using the lactophenol blue method. Aspergillus, Alterneria and Penicillium were the major groups of molds that were identified. Aspergillus and Penicillium species have also been isolated in degutted Mopani worms (Mujuru et al., 2014). The interaction effect between storage time, storage environment and type of package was found to be highly significant $(\mathrm{P}<0.001)$. The effect of the individual factors; storage environment, time and type of packaging was also significant $(\mathrm{P}<0.05)$ on all the microbial parameters analyzed.

During storage, most drastic increase in TVC under ambient conditions was seen at 45 days while in refrigeration the drastic increase was delayed to 135 (PE) and 180 (PL) days. In ambient storage the first 45 days of storage seems to have coincided with the log phase where the growth and multiplication rate in 
microorganisms is usually very high. In the subsequent sampling stages the growth rate was reduced and this could be attributed to factors such as competition and reduction in nutrients (Foods, 2001). In refrigerated storage, the log phase seems to have been delayed to 135 days in PE and 180 days in PL packages. This may be due to a reduction in temperature that leads to an increase in the lag phase of microbial growth (Foods, 2001). Among the different packages used, increase in microorganisms detected was in the order PP>PE $>\mathrm{PL}$. At the end of the experiment, microbial count was higher in PP packages than in the other packages. The woven PP package had a higher permeability to both gases and water vapor that could have favored a higher rate of microbial growth. Different authors have also noted that polyethylene packages have a higher permeability to gases and water vapor than plastic polypropylene packages (Day, 1995; Allahvaisi, 2012). Permeability to relative humidity among the packages could have interfered (caused it to increase) with the water activity of the samples thus promoting microbial growth (Foods, 2001).

\subsection{Effect of Storage Time, Storage Environment and Type of Package on the Color Stability of the Adult House Cricket Meal}

Results for color change in semi-processed adult house cricket meal are presented in table 5 .

Table 5. Color changes in semi-processed adult house cricket meal during storage in different packages and conditions.

\begin{tabular}{|c|c|c|c|c|c|c|c|}
\hline \multirow{2}{*}{$\begin{array}{l}\text { Packaging } \\
\text { material }\end{array}$} & \multirow{2}{*}{$\begin{array}{l}\text { Storage } \\
\text { time } \\
\text { (Days) }\end{array}$} & \multicolumn{2}{|l|}{ Hue angle } & \multicolumn{2}{|l|}{ Chroma } & \multicolumn{2}{|c|}{ Total color change } \\
\hline & & Ambient & Refrigeration & Ambient & Refrigeration & Ambient & Refrigeration \\
\hline \multirow[t]{5}{*}{$\mathrm{PE}$} & 0 & $78.4 \pm 0.4^{\text {def }}$ & $78.4 \pm 0.4^{\mathrm{def}}$ & $14.5 \pm 0.2^{\mathrm{abcd}}$ & $14.5 \pm 0.2^{\mathrm{abcd}}$ & & \\
\hline & 45 & $82.0 \pm 0.4^{\mathrm{abc}}$ & $82.5 \pm 0.4^{\mathrm{bc}}$ & $16.0 \pm 0.1^{\mathrm{abc}}$ & $16.3 \pm 0.5^{\mathrm{c}}$ & $2.4 \pm 0.9^{\mathrm{ab}}$ & $3.0 \pm 1.3^{\mathrm{b}}$ \\
\hline & 90 & $82.1 \pm 1.3^{\mathrm{abc}}$ & $81.9 \pm 0.1^{\mathrm{abc}}$ & $14.7 \pm 0.5^{\mathrm{abcd}}$ & $15.1 \pm 0.5^{\mathrm{abcd}}$ & $2.1 \pm 1.1^{\mathrm{ab}}$ & $1.8 \pm 0.6^{\mathrm{ab}}$ \\
\hline & 135 & $83.0 \pm 1.6^{\mathrm{c}}$ & $81.1 \pm 0.5^{\text {abcef }}$ & $14.9 \pm 0.5^{\mathrm{abcd}}$ & $15.9 \pm 0.9^{\mathrm{abc}}$ & $1.8 \pm 0.7^{\mathrm{ab}}$ & $1.6 \pm 0.7^{\mathrm{ab}}$ \\
\hline & 180 & $83.3 \pm 0.7^{\mathrm{c}}$ & $78.7 \pm 2.3^{\text {adef }}$ & $15.3 \pm 0.3^{\mathrm{abc}}$ & $14.2 \pm 1.1^{\mathrm{abd}}$ & $1.5 \pm 0.3^{\mathrm{ab}}$ & $1.4 \pm 0.4^{\mathrm{ab}}$ \\
\hline \multirow[t]{5}{*}{ PL } & 0 & $78.4 \pm 0.4^{\text {def }}$ & $78.4 \pm 0.4^{\mathrm{def}}$ & $14.5 \pm 0.2^{\mathrm{abcd}}$ & $14.5 \pm 0.2^{\mathrm{abcd}}$ & & \\
\hline & 45 & $71.1 \pm 1.5^{\mathrm{g}}$ & $72.7 \pm 0.7^{\mathrm{g}}$ & $14.3 \pm 0.4^{\mathrm{abcd}}$ & $15.4 \pm 0.2^{\mathrm{abc}}$ & $2.1 \pm 0.6^{\mathrm{ab}}$ & $2.8 \pm 1.0^{\mathrm{b}}$ \\
\hline & 90 & $77.3 \pm 0.3^{\mathrm{d}}$ & $79.7 \pm 1.5^{\text {abcdef }}$ & $14.4 \pm 0.6^{\mathrm{abcd}}$ & $15.7 \pm 0.4^{\mathrm{abc}}$ & $2.1 \pm 1.4^{\mathrm{ab}}$ & $1.8 \pm 1.3^{\mathrm{ab}}$ \\
\hline & 135 & $78.1 \pm 0.8^{\mathrm{def}}$ & $80.6 \pm 1.1^{\text {abcdef }}$ & $13.2 \pm 0.5^{\mathrm{d}}$ & $14.9 \pm 0.6^{\mathrm{abcd}}$ & $1.9 \pm 1.0^{\mathrm{ab}}$ & $1.4 \pm 0.2^{\mathrm{ab}}$ \\
\hline & 180 & $80.2 \pm 1.3^{\text {abcdef }}$ & $77.9 \pm 1.7^{\mathrm{de}}$ & $14.0 \pm 0.4^{\mathrm{ad}}$ & $14.4 \pm 0.9^{\mathrm{abcd}}$ & $1.7 \pm 0.2^{\mathrm{ab}}$ & $1.2 \pm 0.5^{\mathrm{ab}}$ \\
\hline \multirow[t]{5}{*}{ PP } & 0 & $78.4 \pm 0.4^{\text {def }}$ & $78.4 \pm 0.4^{\mathrm{def}}$ & $14.5 \pm 0.2^{\mathrm{abcd}}$ & $14.5 \pm 0.2^{\mathrm{abcd}}$ & & \\
\hline & 45 & $78.9 \pm 0.2^{\text {abdef }}$ & $73.1 \pm 1.1^{\mathrm{g}}$ & $14.9 \pm 0.1^{\mathrm{abcd}}$ & $16.1 \pm 0.5^{\mathrm{bc}}$ & $1.6 \pm 0.2^{\mathrm{ab}}$ & $4.4 \pm 1.1^{\mathrm{b}}$ \\
\hline & 90 & $\mathrm{Sp}$ & $78.9 \pm 0.4^{\text {abdef }}$ & $\mathrm{Sp}$ & $15.8 \pm 1.1^{\mathrm{abc}}$ & $\mathrm{Sp}$ & $3.2 \pm 2.5^{\mathrm{b}}$ \\
\hline & 135 & $\mathrm{Sp}$ & $81.7 \pm 0.1^{\mathrm{abcf}}$ & $\mathrm{Sp}$ & $15.8 \pm 0.2^{\mathrm{abc}}$ & $\mathrm{Sp}$ & $2.5 \pm 0.5^{\mathrm{ab}}$ \\
\hline & 180 & $\mathrm{Sp}$ & $80.4 \pm 0.7^{\text {abcdef }}$ & $\mathrm{Sp}$ & $15.2 \pm 0.6^{\mathrm{abcd}}$ & $\mathrm{Sp}$ & $1.4 \pm 0.9^{\mathrm{ab}}$ \\
\hline
\end{tabular}

Data are means \pm standard deviations. Means in the same column or row within a single parameter sharing common letters are not significantly $(\mathrm{P}>0.05)$ different. Sp; Spoiled; $\mathrm{PE}=$ Polyethylene; $\mathrm{PL}=$ Plastic; $\mathrm{PP}=$ Polypropylene.

The hue angle and Chroma values of freshly boiled and solar dried adult house cricket were 78.4 and 14.5 respectively. In ambient storage, there was a significant decrease in hue angle in PL and PP packages for the first 45 days followed by a significant increase at 90 days after which the value did not change significantly. Sample packaged in PE showed a significant increase at the $45^{\text {th }}$ day in hue angle after which it was relatively constant with no further significant $(\mathrm{P}>0.05)$ changes. The combined effect of storage time, environment of storage and type of package was highly significant $(\mathrm{P}<0.001)$. The chroma values were relatively constant throughout the entire storage period. Consistently higher values were seen in samples stored in ambient conditions than in refrigerated samples but there were no significant differences $(\mathrm{P}>0.05)$. The combined effect of storage time, the environment of storage and type of package was significant $(\mathrm{P}<0.001)$. The total color change indicates the magnitude of the difference between locations in the CIE L*a*b* color system (Isdell et al., 2003).The total color change seems to have been high at the start of the experiment and then steadily decreased with increase in storage time. The color change was higher in ambient storage although there was no variation in significance. This can be attributed to a higher temperature that accelerates degradation reactions in the sample including oxidation thus leading to a greater color change. Similar results were noted in packaged beef, where samples stored at a higher temperature had a greater degree of color degradation (Isdell et al., 2003) The combined effect of storage time, environment of storage and type of package was not significant $(\mathrm{P}>0.05)$. 


\section{Conclusion}

The results show that both chemical and microbial stability of adult house cricket meal during storage significantly $(\mathrm{p}<0.05)$ affected by the combination of the storage environment, time and type of packaging. Packages used in this study maintained the quality attributes of the samples relatively well except the refrigerated woven polypropylene packages that kept the product only for 45 days. The plastic package outperformed the other two packages in maintaining the quality of the stored product in both storage environments. Our processed product even at the baseline level had a high microbial count and thus care should be taken while handling, processing and storage to prevent contamination. Based on both chemical and microbial deterioration of the samples, we would recommend that the samples be stored in plastic packages with a lid for a longer shelf life. If woven polypropylene packages are to be used, it would be advisable to add a layer of polyethylene on the inner side so as to minimize permeability to both air and water vapor and thus prolong the shelf life of the product therein.

\section{Acknowledgements}

This work was supported by the 'INSFEED-Insect feed for poultry and fish production in Kenya and Uganda' (Cultivate Grant No: 107839-001) by International Development Research Centre (IDRC) and Australia Centre for International Agricultural Research (ACIAR).

\section{References}

Adebola, M. O., \& Nusa Halima, M. K. (2014). The Effects of Packaging Materials on Shelf-Life Stability of Garri Bought From Markets in Lapai Niger State Nigeria. Journal of Applied and Environmental Microbiology, 2(1), 12-15. https://doi.org/10.12691/jaem-2-1-3

Akpossan, R. A., \& Due, E. A. (2015). Fatty acids, mineral composition and physico-chemical parameters of imbrasia oyemensis larvae oil with unusual arachidonic acid content. Food and Environment Safety, XIV(4), 358-367.

Allahvaisi, S. (2012). Polypropylene in the Industry of Food Packaging (Unpublished doctoral dissertation). University of Azad, Tehran, Iran.

American Oil Chemists' Society (AOCS). (1992). Official methods and recommended practices of the American oil chemists' society. IL; USA

Association of Official Analytical Chemists (AOAC) international. (1999). Official methods of analysis (16 ${ }^{\text {th }}$ ed.). Gaithersburg: AOAC International

Barroso, F. G., Haro, C. De, Sánchez-muros, M., Venegas, E., Martínez-sánchez, A., \& Pérez-bañón, C. (2014). The potential of various insect species for use as food for fish. Aquaculture, 422-423, 193-201. https://doi.org/10.1016/j.aquaculture.2013.12.024

Bligh, E., \& Dyer, W. (1959). A rapid method of total extraction and purification. Can. J. Biochem. Physiol. 37, 911-917

Boran, G., Karac, H., \& Boran, M. (2006). Food Chemistry Changes in the quality of fish oils due to storage temperature and time. Food Chemistry, 98, 693-698. https://doi.org/10.1016/j.foodchem.2005.06.041

Braide, W., Nwaoguikpe, R. N., Oranusi, S. E., Udegbunam, L. I., Akobondu, C., \& Okorondu, S. L. (2011). The effect of biodeterioration on the nutritional composition and microbiology of an edible long- winged reproductive termite, Macroterms bellicosus. Smeathman. Internet Journal of Food Safety, 13, 107-114.

Braide, W., Oranusi, S., Udegbunam, L. I., Oguoma, O., \& Akobondu, C. (2011b). Microbiological quality of an edible caterpillar of an emperor moth , Bunaea alcinoe. Journal of Ecology and the Natural Environment, 3(May), 176-180.

Cambaztepe, F., Cakmakci, S., \& Dagdemir, E. (2009). Effect of some technological parameters on microbiological , chemical and sensory qualities of Civil cheese during ripening. International Journal of Dairy Technology, 62(4), 541-548. https://doi.org/10.1111/j.1471-0307.2009.00536.x

Committee, E. S. (2015). Risk profile related to production and consumption of insects as food and feed EFSA Scientific Committee, 13(October). https://doi.org/10.2903/j.efsa.2015.4257

Ekpo, K. E., Onigbinde, A. O., \& Asia, I. O. (2009). Pharmaceutical potentials of the oils of some popular insects consumed in southern Nigeria. African Journal of Pharmacy and Pharmacology, 3(2), 51-57.

Esther, R., Reis, C., Vasconcellos, A., Policarpo, I. S., Romeu, R., \& Alves, N. (2015). Edible and medicinal 
termites : a global overview. 11, 1-7. https://doi.org/10.1186/s13002-015-0016-4

Flick, G. J., Hong, G., \& Knobl, G. M. (1992). Lipid Oxidation of Seafood During Storage. In Lipid Oxidation in Food (pp. 183-207).

Foods, P. H. (2001). Chapter 3 . Factors that Influence Microbial Growth.Westport, Conn.

Giannuzzi, L., Zaritzky, N. E., \& Andre, S. C. (2004). Original article The effect of temperature on microbial growth in apple cubes packed in film and preserved by use of orange juice. International Journal of Food Science and Technology, 39, 927-933. https://doi.org/10.1111/j.1365-2621.2004.00870.x

Isdell, E., Allen, P., Doherty, A., \& Butler, F. (2003). Effect of packaging cycle on the colour stability of six beef muscles stored in a modified atmosphere mother pack system with oxygen scavengers. International Journal of Food Science and Technology, 38, 623-632.

International Union of Pure and Applied Chemistry (IUPAC). (1987). Standard methods for the analysis of oils, fats and derivatives ( $7^{\text {th }}$ ed.). Oxford: Blackwell Scientific Pub. Ltd.

Jongema, Y. (2011). World wide list of edible insect species , laboratory of entomology. Wagenigen University. URL: http://www.ent.wur.nl/UK/Edible\%2Binsects/Worldwide\%2Bspecies\%2Blist/\%3FWBCMODE\%3DPresent ationUnpublished. Accessed August 2017

Kaleem, A., Aziz, S., Iqtedar, M., Abdullah, R., Aftab, M., Rashid, F., ... Naz, S. (2015). Investigating changes and effect of peroxide values in cooking oils subject to light and heat. FUUAST J.BIOL, 5(2), 191-196.

Kenawi, M. A. (2012). The role of packaging (materials and treatments) in addition to spices extract on stability of frozen buffalo meat product. Lucrari Stiintifice, 55(2).

Kinyuru, J. N., \& Kenji, G. M. (2010). Effect of Processing Methods on the In Vitro Protein Digestibility and Vitamin Content of Edible Winged Termite ( Macrotermes subhylanus ) and Grasshopper ( Ruspolia differens ), 778-782. https://doi.org/10.1007/s11947-009-0264-1

Kinyuru, J. N., Kenji, G. M., \& Njoroge, M. S. (2009). Process Development, Nutrition and Sensory Qualities of Wheat Buns Enriched with Edible Termites (Macrotermes Subhylanus) from Lake Victoria Region, Kenya. African Journal of Food, Agriculture, Nutrition and Development, 9(8), 1739-1750.

Klunder, H. C., Wolkers-rooijackers, J., Korpela, J. M., \& Nout, M. J. R. (2012). Microbiological aspects of processing and storage of edible insects. Food Control, 26(2), 628-631. https://doi.org/10.1016/j.foodcont.2012.02.013

Maionese, P. E. R., Della, E. V., \& Marangoni, V. (2004). Study of an innovative PET (polyethylene terephthalate) packaging for mayonnaise and evaluation of product shelf life. Italian Journal of Food Science, 16(2), 139-150.

Messer, J. W, Behney H.M., \& Leudecke, L.O. (1985). Microbiological count methods. In Standard Methods for the Examination of Dairy Products, pp 133-149. Ricardson G H, ed. Washington, DC: American Public Health Association.

Mossel, D.A.A., Corry, J.E.L., Struijk, C.B., \& Baird, R.M. (1995). Essentials of the microbiology of foods: a text book of advanced studies. Chichester (England): John Wiley and sons 699p.

Mpuchane, S., Gashe, B. A., Allotey, J., Siame, B., Teferra, G., \& Ditlhogo, M. (2000). Quality deterioration of phane, the edible caterpillar of an emperor moth Imbrasia belina. Food Control, 11, 453-458.

Mujuru, F. M., Kwiri, R., Nyambi, C., Winini, C., \& Moyo, D. N. (2014). Microbiological quality of Gonimbrasia belina processed under different traditional practices in Gwanda , Zimbabwe. International Journal of Current Microbiology and Applied Sciences, 3(9), 1085-1094.

Obopile, M., \& Seeletso, T. G. (2013). Eat or not eat: an analysis of the status of entomophagy in Botswana. Food Security Springer, 5, 817-824. https://doi.org/10.1007/s12571-013-0310-8

Opara, M. N., Sanyigha, F. T., Ogbuewu, I. P., \& Okoli, I. C. (2012). Studies on the production trend and quality characteristics of palm grubs in the tropical rainforest zone of Nigeria. Journal of Agriculture and Technology, 8(3), 851-860.

Parajulee, M. N., DeFoliart, G. R., \& Hogg, D. B. (1993). Model for Use in Mass-Production of Acheta domesticus ( Orthoptera : Gryllidae ) as Food. Journal of Economic Entomology, 86(5), 1424-1428.

Rumpold, B. A., \& Schluter, O. K. (2013). Nutritional composition and safety aspects of edible insects. Mol. 
Nutri. Foof Res. 2013, 57(802-823), 802-823. https://doi.org/10.1002/mnfr.201200735

Shahidi, F. (1994). Oxidative stability of oil from blubber of harp seal ( Phoca groenlandica ) as assessed by NMR and standard procedures, 27, 555-562.

Stannard, C. (1997). Development and use of microbiological criteria for foods. Food Science and Technology Today, 11, 137-177.

Toci, A. T., Neto, V. J. M. F., Torres, A. G., \& Farah, A. (2013). LWT - Food Science and Technology Changes in triacylglycerols and free fatty acids composition during storage of roasted coffee. LWT - Food Science and Technology, 50(2), 581-590. https://doi.org/10.1016/j.lwt.2012.08.007

Van Huis, A., Van Itterbeeck, J., Klunder, H., Mertens, E., Halloran, A., Muir, G., \& Vantomme, P. (2013). Edible insects Future prospects for food and feed security.

\section{Copyrights}

Copyright for this article is retained by the author(s), with first publication rights granted to the journal.

This is an open-access article distributed under the terms and conditions of the Creative Commons Attribution license (http://creativecommons.org/licenses/by/4.0/). 